\title{
Ethical Theory in Classic German Philosophy Then and Now
}

\author{
Ewa Nowak \\ (Adam Mickiewicz University of Poznań; Poland; ewanowak@amu.edu.pl) \\ ORCID: 0000-0002-5722-7711
}

\section{Tom Rockmore}

(Peking University; China; tom.rockmore@icloud.com)

ORCID: 0000-0003-4446-335X

\section{Lara Scaglia}

(Warsaw University; Poland; l.scaglia@uw.edu.pl)

ORCID: 0000-0002-7148-7456

\section{Rainer Adolphi}

(Technische Universität Berlin, Germany; rainer.adolphi@tu-berlin.de)

The volume brings together contributions in the spirit embodied by Marek J. Siemek († 2011) and Jakub Kloc-Konkołowicz († 2021), two Warsaw philosophers truly devoted to Classical German Philosophy. They were simultaneously in a relationship between thinker and adept, and thinker and thinker. They both taught philosophy, with a strong emphasis on classic German philosophy, at Warsaw University. Under the theme "Ethical Theory in Classic German Philosophy Then and Now," students and companions continue their discussions with both of them.

The circle of students that emanated from the work of Marek J. Siemek was and is one of the most fruitful in the recent philosophical landscape in Poland. This circle followed impulses from the thought of German Idealism. What was special about it from the beginning was that this circle did not work from the assumption common in many other countries that from the great figures of that philosophical epoch one had to adopt a single one the absolute point of reference and truth. They saw Kant, Fichte, Hegel and Marx as the expression of a common awakening of thought that continues to have an effect today, 
and which has lost none of its relevance. Discussing a question with Hegel did not have to mean therefore being against Kant or Fichte, and vice versa. It was not about demarcations and the formation of camps, but about connections and the historical evolution of key concepts, such as modern freedom and socialisation. Included in this was also always the perspective that this epoch of thought was not necessarily opposed to Marx's thought. The social motivation and thought of Marx were not viewed as the end, not the burial of the philosophy of German Idealism along with its core concerns: the practical and theoretical; the transcendental, speculative and situated; social, historical and linguistic; the unconditional ("realm of freedom") and conditional ("realm of necessity"). Even in his first encounters with German Idealism, Siemek immediately knew the way out of the atomistic and "monological" "impasse of subjective-idealistic 'ego philosophy"'. They are all, according to Siemek, connected by a common modern philosophical humanism. The latter can be defined in particular by individual self-determination and self-consciousness mediated by rational and respectful intersubjective relations. Moreover, this kind of humanism is regulated by normativities with justifications from the discourse itself. As Siemek himself puts it in a nutshell:

A conversation, therefore, implies that the Other, while still being strange, ceases to be an enemy, a target of aggression, and begins to be a still unknown but already preliminarily accepted partner, i.e. potentially at least an equal subject. It is precisely this mutual recognition, even if only in the most rudimentary form, that enables and sets in train the whole process of dialogic exchange of 'requests' and 'replies'. This recognition carries with it the principle of reciprocity as an irreplaceable, truly 'transcendental' foundation of not only all human interactions and relations, but also of the self reciprocating 'myself to,' which creates the identity of a single human being as a subject. The subjectivity principle, which has dominated classical philosophy and European culture, now emerges even more clearly as a socially and historically shaped product of this original communicative intersubjectivity (Siemek 2000, 38).

A second feature of the intellectual legacy of Siemek and his students was and is to take up current challenges in the ethical, social and political spheres, juxtapose them with divergent contemporary debates and finally explain them in terms of Classical German philosophy. Following Hegel, Siemek was convinced that philosophical tools and philosophy itself can strengthen modern societies and enable them to deal with the divisions and conflicts that define them after their unity has been lost. In his essay "On the Basic Concept of a Social-Transcendental Philosophy", Siemek described the difference between "weak" and "strong" conceptions of philosophising and philosophy. "Strong philosophy" (or "social epistemology") is anchored in the rational, self-critical, self-constituting, social-dialogical element, as already invented in the Socratic "episode" in ancient Athens. "Philosophy itself can be seriously pursued today only insofar as it is understood first and foremost as social philosophy" (Siemek 2020) and provides instruments for coping with the social divide. According to Hegel's The Difference Between Fichte's and Schelling's System of Philosophy, division is the very source of philosophy's need. 
Jakub Kloc-Konkołowicz shared Marek Siemek's appreciation of the radical primacy of the practical in Fichte - namely of unconditional activity qua the "transcendental" model of any "setting", and thus also the "law-giving" activity of an intelligent subject - activity that then manifests and realises itself as a fully conscious, interactive and empirically acting intersubjectivity and sociability. However, instead of following Siemek's socialtranscendental thought, Kloc-Konkołowicz took his own path. He attempted to redefine reciprocal recognition, namely as an applicable orientation principle or normative principle, which was to be placed at the intersection between Fichte's a priori and the empirical doctrine of intersubjectivity. He then applied Fichte's recognition principle "to contemporary social circumstances and thus concretise it differently from him" (KlocKonkołowicz 2015, 157) - with important consequences for the concept of law (all too formalised in Kant), which is to be connected with its own activity, or "the concrete realisation of law through action and in action" (ibid., 158) should come into connection. Only in this way would law fully achieve its practical validity, Kloc-Konkołowicz claims, and comply with the "apellative" as well as "counterfactual" sense of Fichte's doctrine of law (ibid., 158). Through this, too, the other fellow-subject or fellow-citizen would be recognised in its "human form". Consequently, recognition would also take on a real shape as "interaction through concepts" (mutual response to an equally mutual "demand", in a thoroughly discursive mode).

Recognition as a socio-philosophical (descriptive) and normative concept developed by Fichte, and as a thoroughly contemporary concept, determined the way Kloc-Konkołowicz attempted to interpret the tensions and challenges, conditions and principles, of a modern, self-acting socialisation dynamic and the further selftransformation of society, engaging with M. Siemek, A. Honneth, R. Forst, O. Höffe, L. Siep, J. Rawls, and many others. At the same time, Kloc-Konkołowicz knew how to correct the one-sided, metaphysical or even anti-liberal image of Fichte that emerges all too quickly - through his own comprehensive and concretising interpretations. Recognition is ultimately a normative source of "the mutual commitment to action and reflection" (ibid., 184). Kloc-Konkołowicz never abandoned the transcendental "structure" of such socionormative development that shaped him as a student of Siemek.

With the following thematic special volume, we present a companion to the legacy of Siemek and Kloc-Konkołowicz, with a focus on ethical and social theory originating from free action as a very human feature - then and now. The authors explore the potentials of the most important ethical themes of the Classical German philosophers: from Kant's concept of freedom to the approaches to action of Hegel, Marx and Cieszkowski. The emergence of moral freedom in Kant is the main topic of Jacinto Rivera de Rosales' contribution. We mourn the death of Professor Rivera de Rosales, who passed away in October 2021. He focuses on the concept of virtue and distinguishes four main stages on the way to the realisation of moral freedom. After examining the original possibility of being free, or original innocence, in which freedom is seen as the capacity to initiate a 
series of phenomena in the world, he considers radical evil, which corrupts the basis of maxims. However, this does not imply the impossibility of a change of heart, i.e., an inner conversion to the good, which does not mean the abolition of our desire for happiness, but rather promotes the search for its satisfaction within the framework of the moral law. Finally, he focuses on the process of the development of virtue, which reaches immortality, and on the importance of the ethical community, conceived both as an invisible church and as a rational social and legal community. This last moment is seen from our finite and free perspective as an ideally always open task.

Lara Scaglia focuses on education as a core function of reason in both Kant's and Fichte's theories, and as an exemplary case of the dynamic tension between particularity and universality. In particular, the author emphasises the importance of education for Kant, which is already present in the pre-critical works and to which Kant dedicated some of his lectures. Education is seen as essential for the humanisation of man and as an aid to moral judgement and the practice of virtue. Following Kant, in his lectures on the Vocation of the Scholar, The Vocation of Man and The Characteristics of the Present Age, Fichte presents education as the best means to aspire to our vocation and become proper moral agents.

The contribution by Elena Paola Carola Alessiato deals with Fichte's action and the pursuit of freedom. The author makes clear that freedom (in terms of Tathandlung) is the core concept of Fichte's thought, which connects all other components and determines the goals of a philosophy of action. She argues that freedom can be seen on the one hand (from a normative point of view) as characterised by the dynamic process of finitude and infinity, and on the other hand (from a moral and social point of view) as the actual and authentic task and determination of human action. Consequently, it is immoral to abandon our infinite vocation and succumb to the power of feelings, such as resignation and fear.

Rainer Adolphi's contribution combines fundamental social theoretical reflections with concrete problems of today's societies. He asks what can block or prevent the realisation of normatively necessary recognitions. Discourses of "identity" have a decisive function here, which often conceal (or are even supposed to conceal) real social problems and tasks. In a sense, the article discusses the complementary side of current theories of recognition. What needs to be considered theoretically is discussed with reference to Hegel, for whom the question of "identity" was not yet significant in his conception of Sittlichkeit. But from a Hegelian point of view, "identity" must be thought dynamically so that it does not become a backward-looking social topos against the development of modern forms and transnational responsibility. With Hegel, one can thereby show how difficult this is - and how great is the pull of simple "identity" answers and their politics of history. A mature political culture is a long process of experiences and learning. The contribution follows a basic conviction of the work of Siemek and Kloc-Konkołowicz: Being a 'Hegelian' must also mean not stopping at Hegel. In short a Hegelian must begin 
with Hegel in the ongoing social and historical debate that does not end Hegel with but in Hegelian fashion is carried beyond his thought.

In her contribution, Erzsébet Rózsa examines modern "subjective" freedom in Hegel as a historical innovation; the specifics of this freedom include, on the one hand, the permanent complication of human-social practices, but also, on the other hand, the (always deficient) self-regulation of these practices. The concept of subjective freedom has given rise to the modern ideals of freedom, fundamental rights (e.g., human rights), values and norms. In Hegel's 1820 Philosophy of Right, subjective freedom is presented as universally normative and at the same time socially and historically situated; both in its "immediate" and "mediated" aspects. The author shows how the users of this freedom, including a variety of their ways of life, deal with tensions between different kinds of "morality" [Sittlichkeit]. Conflicts and antagonisms challenge modern subjects, necessitating a constant effort at reconciliation. An example of this dynamic is marriage and the right to divorce as representatives of a specific "morality".

Ivo Minkov's contribution focuses on Hegel's Absolute Subject and interprets the dialectic as a possible course of the spiritual development of the absolute subject, which is seen as a necessary result of speculative and logical formation, and at the same time as a phenomenological process of realising its essence. The author inquires into the methodology of this dynamic: from the idea of freedom constructed in logic as a speculative and logical outcome, through its function in the transition from the subjective to the objective mind, and then in the process of mediations in the realm of the objective mind. In this way, Minkov aims to outline a project of speculative ethics within a framework in which a mental evolution and the construction of being [Gedachtsein] is realised through sublation, preservation and accumulation in infinite perfection, on both the ontological and methodological levels.

The relationship between theory and practice is the focus of Andreas Arndt's article. Starting from August von Cieszkowski's idea that we are at a turning point in history, where facts become "deeds," he tries to understand what a "deed" means. He looks at Hegel's development of the concept of freedom and focuses on two models of understanding action. One leads to Fichte's act of doing, the other - developed later by Marx - considers action as activity on objects (labour). Hegel's concept of the act presupposes the dialectical process of absolute reality, which it is the goal of philosophy to grasp and understand. "Work is also that activity through which the spirit liberates itself." While for Hegel human praxis is to be understood as the practical and theoretical behavior towards the world (nature as well as the social world), according to Marx praxis is objective mediation, Arndt stresses. In contrast, the unconditional or absolute deed could directly be reality in the real-philosophical sense, as Cieszkowski meant it.

Tom Rockmore provides an original contribution on Marx's relationship to Fichte. Although this topic is not often explored, it is fundamental to understanding Marx's contribution and his position within so-called Classical German Philosophy. Some 
interpreters consider Marx's materialism as evidence of his break with philosophy. However, this position is inaccurate, since materialism must also be regarded as strictly philosophical. The philosophical relevance of Marx is emphasised by Korsch and Lukács; the latter in particular, who wanted to show that Marx went beyond German Idealism in his response to Hegel, points to the importance of Fichte for Marx's conception of the subject. Based on his theory of the subject and human activity, Marx's account (which is directed against Hegel) in this way evoked Fichte's approach to human activity in reaction to Kant. Certainly, the two positions cannot be reduced to one another, but Marx's position is similar to Fichte's, and not only that: it goes back in the Western tradition at least as far as Aristotle, who developed a theory of life as activity in the Nicomachean Ethics.

\section{References}

Kloc-Konkołowicz J. 2015. Anerkennung als Verpflichtung. Klassische Konzepte der Anerkennung und ihre Bedeutung für die aktuelle Debatte. Würzburg: Königshausen \& Neumann.

Siemek M. 2020. Inedita, ed. by E. Nowak. Warsaw: Warsaw University Editions. Siemek M. 2000. „Two Models of Dialogue,“ Dialogue and Universalism 11:37-55. 